\title{
Partita 3, para violoncelo solo: preparação de performance depois das notas sobre o fluxo de energia
}

\author{
Silvio Ferraz \\ Universidade de São Paulo \\ William Teixeira \\ Universidade Federal do Mato Grosso do Sul
}

\begin{abstract}
Resumo: $O$ artigo relata o processo de construção da performance de uma peça em vias de ser estreada a partir dos diálogos entre o compositor e o instrumentista, dos mais prosaicos aos mais elaborados conceitualmente. A principal questão a ser explorada é o conceito de "fluxo de energia", que permeia toda a discussão. O conceito parte de sua concepção pelo filósofo francês Gillbert Simondon e alcança aplicabilidades enquanto mediação entre o ato composicional e 0 ato interpretativo, funcionando como um arcabouço que fuja de referencialidades linguísticas ou subjetivismos quasi-românticos. Desse modo, pretende-se apresentar o conceito em funcionamento, além de apresentar uma anatomia da peça em si, que perpassa o pensamento composicional e o pensamento envolvido em sua performance, oferecendo uma abordagem analítica profundamente colaborativa.
\end{abstract}

Palavras-chave: Criação colaborativa. Práticas criativas. Performance musical. composição musical. Música contemporânea.

Em 2016 foi finalizada a composição da peça Partita 3: linhas, para violoncelo solo${ }^{1}$. Foi composta tendo em vista as diversas colaborações entre o violoncelista William Teixeira e o compositor Silvio Ferraz em duas versões de um concerto para violoncelo, 6 curtas peças solo a partir dos Ricercari para violoncelo solo de Domenico Gabrielli e colaborações nas realizações de peças compostas anteriormente para violoncelo solo, câmara ou violoncelo e orquestra.

\footnotetext{
${ }^{1}$ Uma gravação em vídeo desta peça, executada pelo autor, acompanha este artigo.
} 

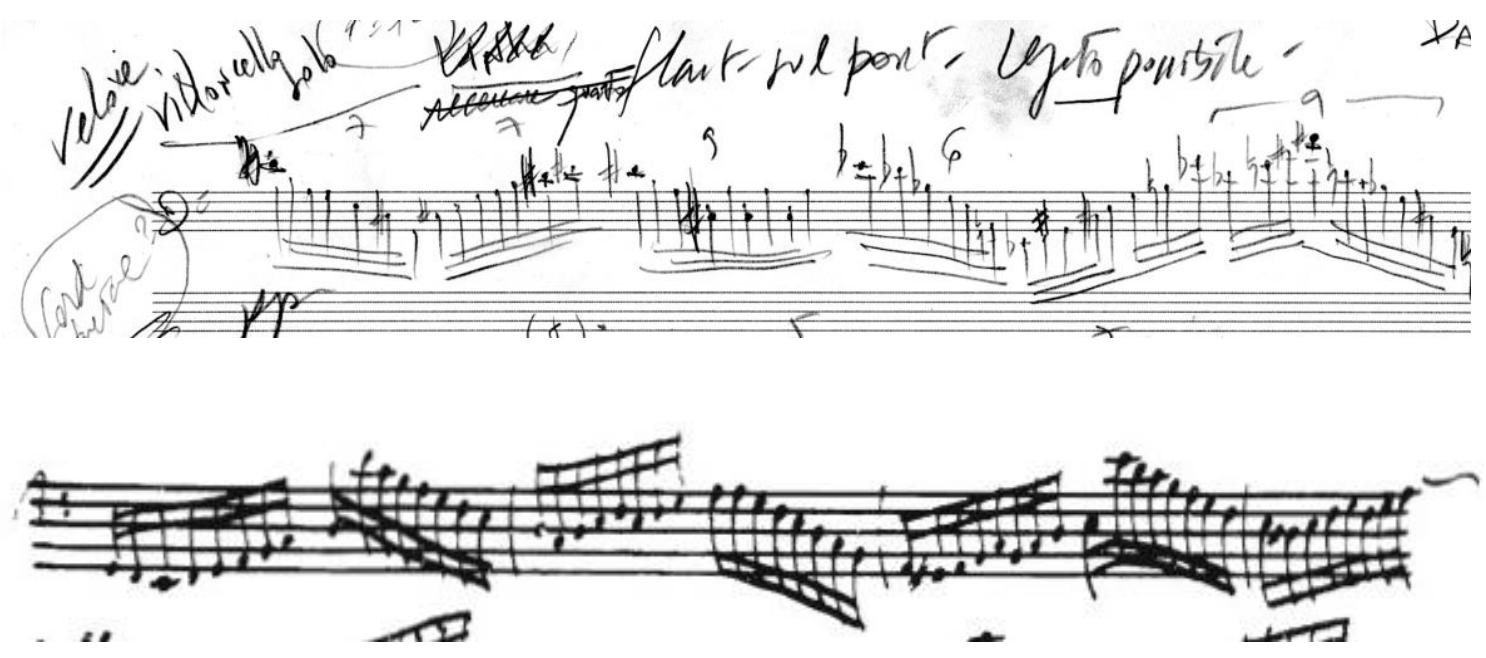

Figura 1: primeira linha do rascunho de Partita 3, de Silvio Ferraz, e compassos 27 a 30 de Ricercari $5^{\circ}$, de Domenico Gabrielli

Destas colaborações é que nasce a primeira frase desta Partita, uma espécie de deformação harmônica da parte central do $5^{\circ}$ Ricercari de Domenico Gabrielli. O histórico de colaborações entre instrumentista e compositor vai além desta partitura e também se dá em mais de uma dezena de artigos publicados em colaboração, o que sem dúvida é parte da realização. Muitas vezes inclusive fazendo interferir a realização de uma obra anterior sobre outra, e que nem sempre corresponde ao que o compositor tem em mente na obra seguinte. Tal aspecto é relevante ao considerarmos os trabalhos em colaboração, que são muitas vezes atravessados por aspectos de contágio, e que exigem a cada nova peça um novo trabalho de modo que, ao considerar o histórico de colaborações, tal histórico não venha a interferir de modo equívoco em trabalhos futuros.

\section{A primeira leitura (Silvio e William)}

S - Na primeira leitura uma das dúvidas foi a do arco arrestato: o que o compositor queria com esta ideia? Trata-se de uma bariolage mas sem mover o arco na vertical, apenas fazer o giro de bariolage produzindo um leve ruído ao passar sobre as cordas. Para resolver o problema trocamos algumas mensagens de vídeo. Recebi de William duas versões, uma primeira com muita presença de arco e outra com menos, mas enviei então uma em que toquei com ainda menos presença e de maneira mais percussiva. Mas ouvindo o resultado da primeira leitura da peça ${ }^{2}$, o gesto no lugar em que ele aparece na peça, veio a ideia de que tal qual toquei havia ruído demais, e que deveria existir um lugar entre a segunda versão realizada por William e a que eu havia realizado anteriormente. E que esta versão estaria

\footnotetext{
${ }^{2}$ A gravação em áudio desta primeira leitura está anexada ao artigo e é a mesma que mencionamos na seção "Depois da primeira leitura".
} 
realizada não como um objeto isolado, mas como um objeto que é continuidade e lento desaparecimento do anterior. Como o gesto necessita de peso para realização, não alterei da dinâmica; um erro. Pois para o instrumentista continua a ideia de que a passagem é forte, e que o ruído deverá ser forte. O engano ao qual a notação acabaria impondo seria o de pensar o objeto como objeto isolado e não como fluindo entre outros objetos.

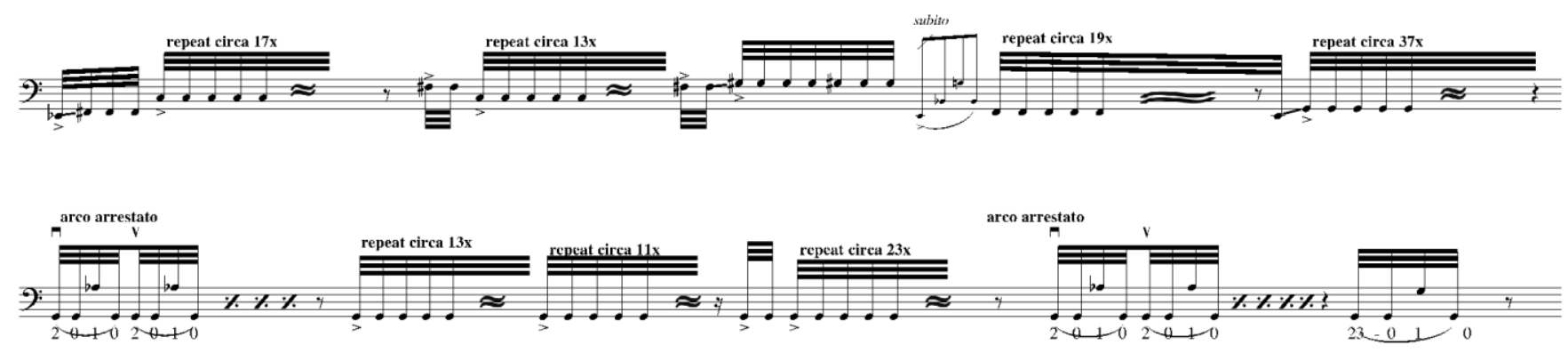

Fig. 2: Partita 3, p. 2, linhas 3-4

W - Meu método para preparar qualquer repertório, mas especialmente do Silvio, envolve em paralelo o estudo de microestruturas e macroestruturas (conceitos que atribuo às ideias trabalhadas nas aulas que tive com Hans Jensen na Northwestern University). Microestruturas são as escolhas dos dedilhados, o cuidado com a pureza da afinação de cada nota, a escolha da região de arco, mudanças de posição, tudo isso "fora do tempo", em andamentos extremamente lentos, buscando a limpeza de cada elemento estrutural. Entretanto essa etapa não faz sentido se paralelamente e desde o início não houver o estudo das macroestruturas, que são os grandes gestos e a as grandes linhas, que abundam nesta peça em especial, demandando toda sorte de resistência e contaminando o próprio estágio microestrutural, revelando decisões técnicas inconsistentes com o objetivo energético final. Essa etapa acontece totalmente no andamento final e já buscando a energia da peça como fora concebida para ser. Nesta peça o estudo dos dois âmbitos em paralelo é particularmente necessário, levando meses para que se contaminem apropriadamente; e é aqui que não vai adiante uma interpretação do tipo leitura-concerto, que já espera obter os resultados finais no primeiro contato com a partitura. ${ }^{3}$ Mas quem se arriscaria a ir para o palco tocar o concerto de Dvorák com apenas uma semana de estudo? É essa a ética, no entanto, que leva muitos

\footnotetext{
3 Silvio - Observo que quando as peças foram encomendadas para concertos específicos elas foram imediatamente realizadas, nunca ficando uma peça sem estréia imediata. Mas não é o caso para peças sem data de estreia prevista, como esta Partita, uma Fantasia para violino, um ciclo de peças para piano (Fantasia). São peças que ficaram paradas anos até que fossem lidas e então realizadas. Ao me associar a muitos intérpretes virtuoses da música contemporânea, como Luís Montanha, Lídia Bazarian, Cassia Carrascoza, Irvine Arditti, Félix Renggli, Alexandre Zamith, Carlos Tarcha, Fábio Presgrave, acabei tendo nestes meu laboratório de escrita. Seus limites técnicos acabaram sendo os meus também, vez ou outra tentando ir além.
} 
performers a avaliarem novas composições como "mal escritas" ou crerem que um compositor "não conhece o instrumento".

Existe, todavia, uma etapa zero, um estágio anterior ao próprio contato instrumental com a partitura, que é a decifragem. Essa decifragem abarca a compreensão da normativa atribuída a cada símbolo da partitura. Essa etapa não se limita a uma simples bula, pois cada símbolo em cada lugar do texto e, sobretudo, para cada compositor, se integra a sua própria singularidade de som e espaço. Há de se imaginar nesse primeiro exame - uma anamnese do texto - o lugar de execução de cada som, as cordas que melhor cabem a cada trecho, a maneira de planejar o fluxo de cada seção e a própria identificação dessas seções que congregam elementos de permanência. É por meio dessa imaginação que uma imagem sonora começa a se formar naquilo que poderia se chamar de ouvido interno (GAGNEPAIN, 2003, p. 9-12). Essa etapa chega a durar meses no caso de uma peça tão complexa quanto a Partita 3, ainda que sua duração efetiva seja de aproximadamente 3 minutos!

O curioso é que a etapa zero também não é zero. Ao inquirir mais profundamente sobre essa estratificação que o processo de construção da interpretação traz consigo, observo a presença de todo o repertório do compositor que já toquei e estudei anteriormente. Não se trata, entretanto, de uma base de preparação plenamente adaptável para os novos casos que uma nova peça carrega consigo, mas uma direção que ora pode ser retomada, mas que por vezes precisa ser desafiada para que a nova peça seja de fato nova em sua singularidade para o intérprete 4 .

Este é o caso de toda a seção inicial da Partita 3 (fig. 3), que compartilha da mesma origem energética e figurativa da sessão fantasia do Ricercar 5 de Gabrielli com a reescrita que o Silvio fez dedicada a mim em 2014 (fig. 4) e com a seção inicial da segunda encarnação de Responsório de Domingo de Ramos (fig. 5), espécie de palimpsesto composto em 2016 após minha performance da primeira versão da peça com a Orquestra de Câmara da USP, sob regência de Gil Jardim, que viria a ser estreada nessa nova apresentação em 2017, com o Orquestra Sinfônica da UNICAMP, sob regência de Cinthia Aliretti.

\footnotetext{
${ }^{4}$ William - Tenho em mente especialmente uma última experiência que me trouxe surpresa, em 2018, ao preparar a obra de Silvio para violoncelo solo, voz e grupo de violoncelos $A$ l interno del cranio, estreada com o Frates Cello Ensemble no Festival Musica Nova, na USP Ribeirão Preto, por se afastar radicalmente do restante da obra do compositor.
} 


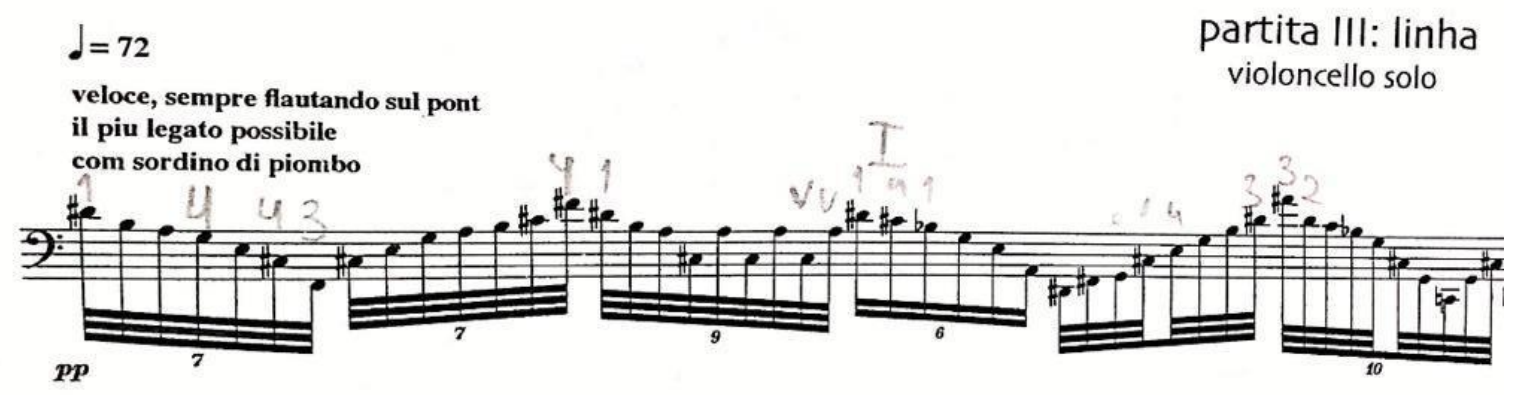

Fig. 3: primeira linha da Partita 3 (com dedilhados do violoncelista)
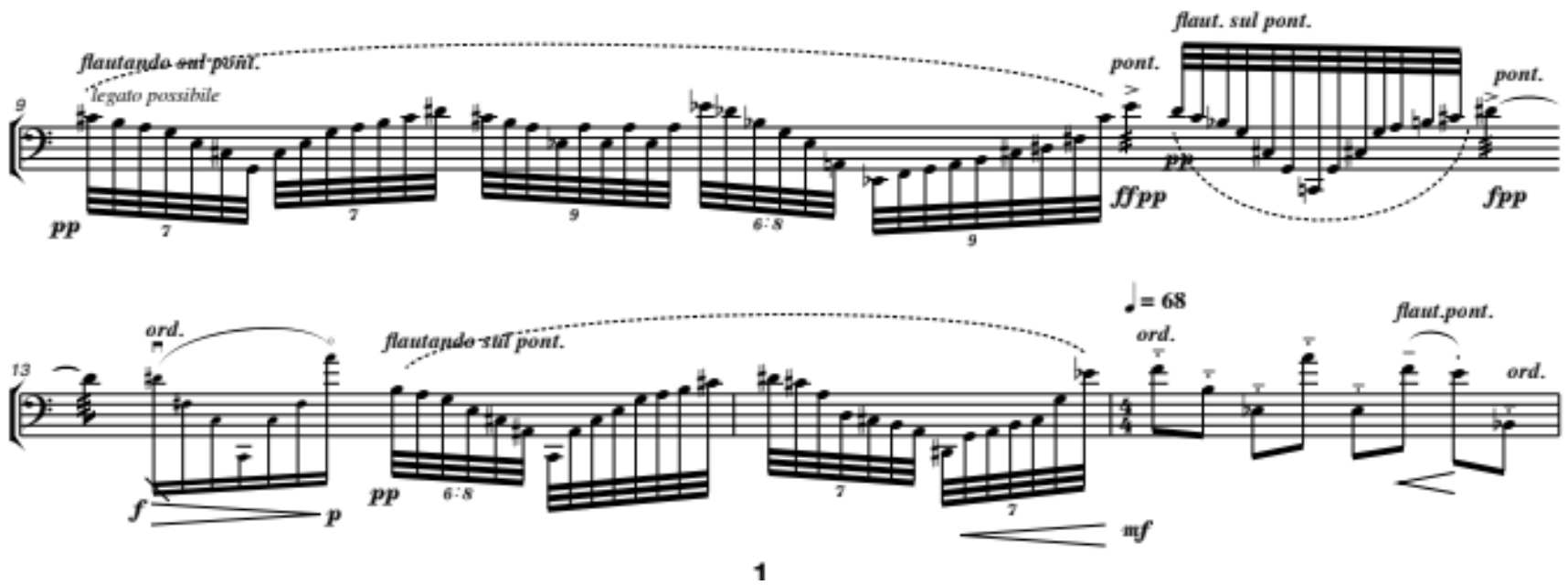

Fig. 4: quarta e quinta linhas de Ricercar secondo, reescrita de Silvio Ferraz sobre o Ricercar 5 de Domenico Gabrielli

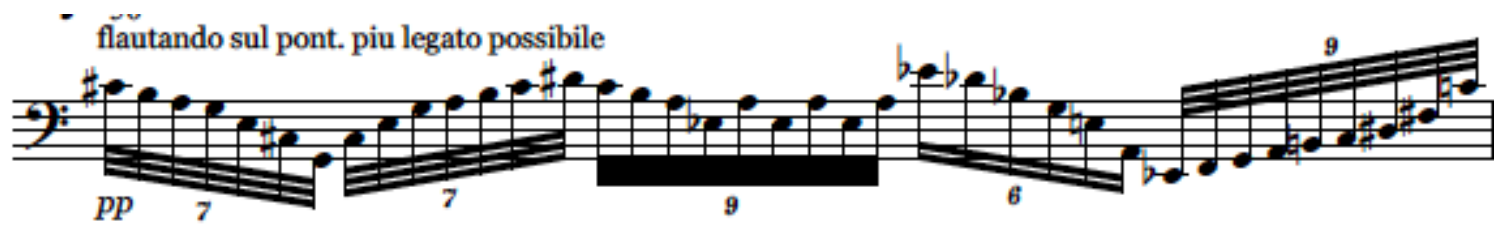

Fig. 5: primeiro compasso do palimpsesto (segunda versão) de Responsório de Domingo de Ramos

As três linhas compartilham de atributos óbvios, que são a velocidade e ferocidade dos gestos, ainda que em dinâmica contida, aliadas à imprevisibilidade rítmica que as quiálteras produzem. Todavia, a simples mudança da primeira nota de dó sustenido para ré sustenido na Partita provoca uma reconfiguração total dos dedilhados e, consequentemente, do gesto como um todo. Embora haja uma certa manutenção do padrão melódico, as alturas escolhidas na Partita necessitam de muito maiores mudanças de corda e de posição, fazendo com que 
os gestos impliquem em um fluxo de energia superior ao dos dois casos antigos. Além disso, a Partita é um grande tour de force, de maneira que esse início já necessite ser um gatilho instantâneo, porém apto a perdurar, diferentemente do Ricercar, onde acontece em uma seção intermediária, e mesmo do Responsório, que embora seja seu começo, pertence a uma seção inicial curta, que dará lugar à orquestra alguns momentos em seguida.

Meu ponto com essa comparação é que embora os dois casos anteriores já tivessem sido estudados por mim, a preparação para a Partita 3 partiu praticamente do zero, esse zero que defino aqui. Um momento zero criado pelo compositor ao reconfigurar totalmente uma figuração musical em um outro contexto discursivo, implicando movimentos corporais e mentais radicalmente distintos; logo, um novo gesto. A isso acrescenta-se o fato de 0 compositor dessa vez prescrever o uso de uma surdina de maior absorção de vibração e, ao mesmo texto, construir uma linearidade tão enérgica, que, em sul ponticello, faz com que a clareza das alturas seja de difícil obtenção.

\section{Depois da primeira leitura (Silvio)}

Depois da primeira preparação, com notas já no lugar, andamentos, dinâmicas, arcadas, passagens de dedos, toda a microconstrução realizada a partir da partitura, observei que seria interessante trabalhar a questão do fluxo de energia da peça.

O que seria este fluxo de energia? No caso, o que estou pensando é no processo de transdução, na passagem ponto a ponto, de "energia de performance". Sendo a "energia de performance" um envelope que reúne, de um lado, a energia sonora (fluxo dinâmico e espectral) e a gestualidade, de ordem proprioceptiva e motora, e de outro aqueles aspectos relativos à escuta, a figura e textura face a repetições, permanências e transformações ou cortes.

Quando falamos de um fluxo de energia, o primeiro aspecto que observo aqui é relativo à noção de permanência (uma nota ou textura do tipo emaranhado/trama/reiteração constante que dure um tempo suficiente para estabelecer o que podemos chamar de uma paisagem sonora contínua e imersiva).

O segundo aspecto seria o que diz respeito à continuidade de transformação, gradual ou abrupto, em que entram em jogo camadas distintas no "feixe do fluxo de performance", deste objeto de escuta, onde uma camada pode ser caracterizada por permanente enquanto outra se transforma. Por exemplo, uma esteira rítmica reiterada isocronamente à qual podem estar associadas notas ou timbres que se transformam gradualmente ou mesmo saltam. Ou ainda a mesma esteira entrecortada por evoluções ou acentos dinâmicos.

Na prática tal qual compreendida na música até as Bagatelas op.9 de Webern ou Farben de Schoenberg, a continuidade vinha de certo modo na simples presença do instrumento. Se nas Bagatelas para quarteto de cordas de Webern o som de cada instrumento muda, de certo 
modo fazendo de cada instrumento fonte sonora múltipla, em músicas mesmo que das ditas vanguardas europeias como nos Klavierstuck VI de Stockhausen, a presença do piano e seu timbre habitual, e a própria construção melódico-harmônica com saltos, escolhas e privilégios de intervalos, acaba garantindo a continuidade ao jogo que figurativamente é compreendido como fragmentado.

Mas, a partir de experiências como a KlangfarbeMelodie nos seus dois modelos, Farben e Bagatelas op.9, em peças de compositores como Berio, nas suas Sequenze, ou Lachenmann, em Pression, no que diz respeito a continuidade teremos apenas a visibilidade do instrumento, que se desfaria em situação acusmática.

O terceiro aspecto seria o de uma continuidade por ressonância, quando um elemento que se mantém permanente, passando de um momento para outro dentro da peça, tem uma característica muito próxima à de uma ressonância, às de algo que continua o estado anterior mas ganhando novas características no estado posterior ${ }^{5}$.

Seriam então três tipos de continuidade, e um quarto, que chamaremos de continuidade por modulação local. O termo é ruim, porque em música modulação tem um lugar já bastante definido. Mas o uso aqui diz respeito à proposta de Gilbert Simondon, quando, ao falar de modulação, fala da relação que se passa entre dois fluxos de energia, um portador e outro modulante, ou duplamente modulante, um de modulação de amplitude e outro de modulação de frequência. Um fluxo de energia $X$ é interrompido por um fluxo de energia $Y$, e no ponto de interseção entre os dois fluxos há a modulação em que o novo fluxo é modulado pelo que recebe do fluxo anterior naquele ponto ínfimo entre um momento e outro. É o exemplo recorrente do corte entre agudíssimo e cluster grave realizado por Ligeti em Atmosphères. $\mathrm{O}$ grave modula a lembrança do agudo, e o agudo que acaba de acontecer modula a escuta do grave que agora se ouve. Neste ponto observa-se uma espessura do presente, fazendo uso de uma ideia de Gérard Grisey: a espessura do tempo. É como se naquele momento o tempo se desdobrasse. ${ }^{6}$

Tendo estes elementos em mente, e a importância dos aspectos de continuidade de um fluxo de energia de performance, após a primeira leitura realizada pelo instrumentista minha interação foi no sentido de escrever um mapa do fluxo de energia que nem sempre está claro na partitura. Lembrando que muitas vezes, nas indicações de partituras estão tempos, dinâmicas, mas é necessário além da decifração a leitura de como se dá a passagem entre um objeto e outro, entre um gesto de performance e outro. Um salto em dinâmica forte, entre

\footnotetext{
${ }^{5}$ Boulez chama atenção a este modo de continuidade de heterofonias convergentes ou divergentes e de suas qualidades gerais da qual tomamos aqui a ideia de "dependência": ponto de chegada ou partida de uma heterofonia, "a heterofonia será ligada, ou seja colada ao antecedente, por um ponto determinado imutável, como uma altura (ou complexo de alturas), ou o silêncio..." (BOULEZ, 1963, p. 140-141).

${ }^{6}$ Em meu artigo "Kairos: ponto de ruptura", apresentei essa ideia de corte em Atmosphères, a qual referimos aqui (FERRAZ, 2015, p. 45-46).
} 
3 cordas e 5 posições do tipo mi1->do\#4 em um violoncelo, seguindo de um trêmulo fortedecrescendo, entre a primeira e a segunda corda como do\#4/sol3, definem dois objetos, mas que se relacionam por continuidade, do tipo ataque-desdobramento. Poderia compreender ideia semelhante em uma obra bastante fragmentada de Mozart, sua Fantasia em Ré menor, quando da sequência de acordes ascendentes sobre Lá Maior, como se fosse um só objeto e não mais 4 acordes, um objeto ataque-desdobramento com ressonância aguda. É o que mapeia Lachenmann em seus tipos sonoros (Cf. LACHENMANN, 2009, p. 37-60). Já uma passagem que envolva um ataque fortíssimo em corda solta e o eco deste gesto na corda vizinha, oitava acima com nota reiterada, este também traz dois objetos e que também se relacionam por ataque-desdobramento. É o que poderia denominar por explicação, um objeto sonoro-gestual é explicado, desdobrado para fora, no objeto seguinte, quase compondo um só objeto que evolui. Tal conexão é diferente daquela de uma passagem melódica descendente, sobre cordas lá e ré, que é cortada por outra grave sobre a corda dó com notas repetidas ou reataques fortes desta mesma nota.

\section{Primeiro parêntesis: a parcialidade da partitura na expressão do pensamento composicional (Silvio)}

A dinâmicas indicadas na partitura, assim como as notas e articulações, nem sempre externam, no entanto, a relação de continuidade do fluxo sonoro. Penso aqui em alguns problemas herdados da tradição melódica, polifônica e homofônica. Tais tradições definem relações funcionais entre os elementos do tipo $X$ em função de $Y$, onde cada instrumento ou "voz" musical, é um dado independente. O primeiro salto foi a passagem da polifonia à noção de acorde da homofonia. Se na primeira cada voz era totalmente independente e todas tinha mais ou menos igual importância enquanto linha a ser seguida, desenhando continuidades paralelas. Com os acordes esta independência desaparece, mas ainda se pede de todas as vozes que sejam equivalentes em termos dinâmicos. Um acorde forte tem todas notas fortes e acentuar uma ou outra ponta do acorde é uma questão de estilo que irá definir o colorido de interpretação dos intérpretes a, b ou c. Mas não é esta a realidade quando um intérprete se defronta com uma composição espectral, de um compositor como Grisey ou Murail. Aqui as notas não são mais elementos independentes de vozes, nem componentes equilibradas e equitativas de um acorde. As notas agora estão emulando frequências de um só som, e a relação dinâmica talvez seja tal que apenas um dos instrumentos ganhe presença, como no início de Partiels e a cada oitava talvez o compositor peça que os instrumentos se relacionem em uma diferença de $16 \mathrm{~dB}$.

Ou seja, estamos diante de um objeto só, as dinâmicas dizem um pouco do que o compositor quer, mas é preciso uma compreensão do que significa acusticamente relações em que a dinâmica cai a cada oitava ou a cada 4 ou 5 parciais. Não está dado na partitura 
este fato, ele vem do conhecimento do pensamento de compositores que tomaram dados espectrais como referência composicional, e isto está expresso em textos, que não são simples anexos decorativos de partituras, mas sim parte definitiva da partitura. Se uma tradição escolástica da música diz que a partitura é tudo, hoje é claro que o "é tudo" é mentira tanto em Corelli quanto Bach, Stockhausen ou Grisey. A partitura é apenas um dos elementos para a construção da performance musical e podemos inclusive dizer que se trata dos elementos de notação mais aproximada e incerta. Observar que Beethoven dá um salto notando gestos, e para tanto se valendo de metrônomo, é uma leitura de partitura que demanda outras leituras. A realização de Debussy sem o conhecimento da técnica de touché pianística proposta por Debussy e transmitida por Maurice Dumesnil, morreria como um simulacro mal-acabado. ${ }^{7} \mathrm{O}$ texto de Dumesnil não é uma observação, uma proposta, mas tem o estatuto de partitura. E Igor Stravinsky dizia o mesmo a respeito dos vídeos e gravações que deixou de suas obras. Não é a interpretação de Stravinsky, mas um adendo a suas partituras e que como tais adendos também é parcial. $O$ fato é que a partitura não traz todos dados necessários sobretudo para que seja compreendida não mais como fluxo de ideias musicais, mas como fluxo sonoro ininterrupto, onde mesmo os cortes são dados de continuidade.

E teríamos ainda como exemplos privilegiados aqueles das colaborações entre compositor e intérprete. Um exemplo de colaboração e a relevância do relato de performance para a realização do que estava em curso no pensamento parcialmente registrado em partitura, é a composição de Sequenza XIV de Luciano Berio - Roham de Saram. As diversas versões anteriores à versão final, o modo de realização do tap no corpo do instrumento, são índices de realização. A prova a incompletude da partitura está na realização desta peça por Éric-Maria Couturier (Ensemble Intercontemporain) e a realização de Roham de Saram, para quem a peça foi escrita e que colaborou com Berio até a última versão da partitura e revisões que não foram incorporadas dado Berio falecer antes de um último encontro entre compositor e instrumentista. O que Berio pensa para dedos, e anota como tap, Saram realiza com dedos e Couturier com batidas espalmadas. Nesta Sequenza, assim como em diversas outras, o tema é o próprio instrumentista, o tema é Saram, sua origem do Sri Lanka, seus modos de improvisação, como observamos no artigo de 2015, Técnica Estendida e Escrita Polifônica em Luciano Berio: Sequenza XIV. ${ }^{8}$

\footnotetext{
${ }^{7}$ Maurice Dumesnil, How to play and teach Debussy (Schroeder \& Gunther: New York 1932).

${ }^{8}$ William - Sobre a presença de um performer pessoalmente envolvido com a criação de um discurso musical, seja em qual nível for, ainda se aplicam os limites que serão apresentados no segundo parênteses deste artigo. Quando toquei a Sequenza XIV de Berio para Roham de Saram em 2014, a realizei com a scordatura requerida pelo compositor na partitura. Ao ouvir o resultado final, Saram disse: "acho que era isso que Berio queria", já que ele próprio não utilizava a scordatura prescrita pelo compositor por considerar um esforço desnecessário diante da desestabilização de afinação causada no instrumento em meio a um recital com outras peças.
} 
Trazemos este exemplo apenas para reforçar a ideia de que existe uma ideia do compositor, mas ela está apenas parcialmente expressa na partitura, o que faz com que um material suplementar tenha sua pertinência primeira na realização de uma obra. Fazendo da simples decifração e realização da partitura o que poderemos chamar de uma realização cega.

\section{O fluxo de energia (Silvio e William)}

O que pretendemos trazer neste artigo é a importância do que chamamos de uma continuidade concreta em contraponto à ideia estruturalista de unidade ideal. ${ }^{9} \mathrm{~A}$ retomada de uma continuidade concreta se dá face a novas noções que permitem compreender o fluxo de performance, a reinserção que a etnomusicologia e diversas leituras relativas ao gesto musical fizeram do corpo do instrumentista, do corpo do instrumento, do corpo da sala de concerto, no que chamamos de música ${ }^{10}$. Mesmo as práticas de compositores tornaram este corpo incontornável, como o próprio Berio em suas Sequenzi, o trabalho de compositoresdramaturgos como Dieter Schnebel e Georges Aperghis. ${ }^{11}$

Junto a esta presença do corpo está também a crescente ideia de que a escuta musical é transmodal, aliás de que toda escuta é transmodal. Neste sentido atuam na escuta de um fluxo de performance não apenas o visual direto da performance, do espaço, mas também o visual presente na imagem da figura musical, o tátil da noção de textura, o proprioceptivo e motor da noção de gesto, além das relações simbólicas que um fluxo deste tipo dispara; e todas essas instâncias se afetam e se modulam mutuamente ${ }^{12}$. Nesse sentido, um conceito como o de unidade começa a fazer água e trazer de volta a ideia de uma continuidade concreta nos parece oportuno.

O fato é que carece à continuidade concreta uma teoria musical, dado que a grande parte das teorias da música se dedicaram aos desdobramentos da análise forjada a partir da música dodecafônica e serial, ou seja, partindo de um paradigma estrutural ${ }^{13}$. Um ponto de partida, no entanto, seriam os estudos compilados por Albert Bregman em Auditory Scene Analysis (1994). Em seu livro Bregman traz diversas experiências relativas justamente aos elementos que forjam a continuidade ou descontinuidade de um fluxo auditivo em uma

\footnotetext{
${ }^{9}$ A este respeito consultar Morgan, 2003, p. 7-50, e Maus, 1999, p. 171-92.

10 Segundo Roland Barthes: "O estruturalismo é essencialmente uma atividade [...]. O objetivo de toda a atividade estruturalista [...] é reconstruir um objeto. A estrutura é, pois, de fato, um simulacro do objeto" (BARTHES apud DOSSE, 2007, p. 277). François Dosse comenta, acrescentando que "Essa atividade estruturalista é encarada como uma 'atividade de imitação' [apud BARTHES], mimese estabelecida não sobre uma analogia de substância, mas de função [...]. A esse respeito, Barthes coloca num mesmo plano essa atividade que se serve da linguística para construir uma ciência da estrutura e o nouveau roman de Butor, a música de Boulez e a pintura de Mondrian, cujas composições participam do mesmo simulacro do objeto que o trabalho semiológico." (DOSSE, 2007, p. 277).

11 Ver D. Schnebel, Son et Corps, Dijon: Presses du réel, 2017.

12 Sobre o conceito de "gesto musical transmodal" ver o quinto capítulo da tese de Teixeira, 2017.

${ }^{13}$ Um forte exemplo deste fato são as análise de Edward T. Cone, o pequeno manual de Nicolas Cook, e a série de trabalhos de analistas na esteira de Allan Forte, J.Strauss, Riemann e outros.
} 
determinada cena. Interessante observar a presença do pensamento de Bregman entre compositores do espectralismo e sua contribuição naquele que talvez seja o principal livro sobre o timbre enquanto dado composicional, Le timbre métaphore pour la composition organizado por Jean-Baptiste Barrière (1991).

O que temos é um modelo simples que buscamos exemplificar na figura abaixo, onde cada ponto de um fluxo é conectado ao outro por transmissão de energia.

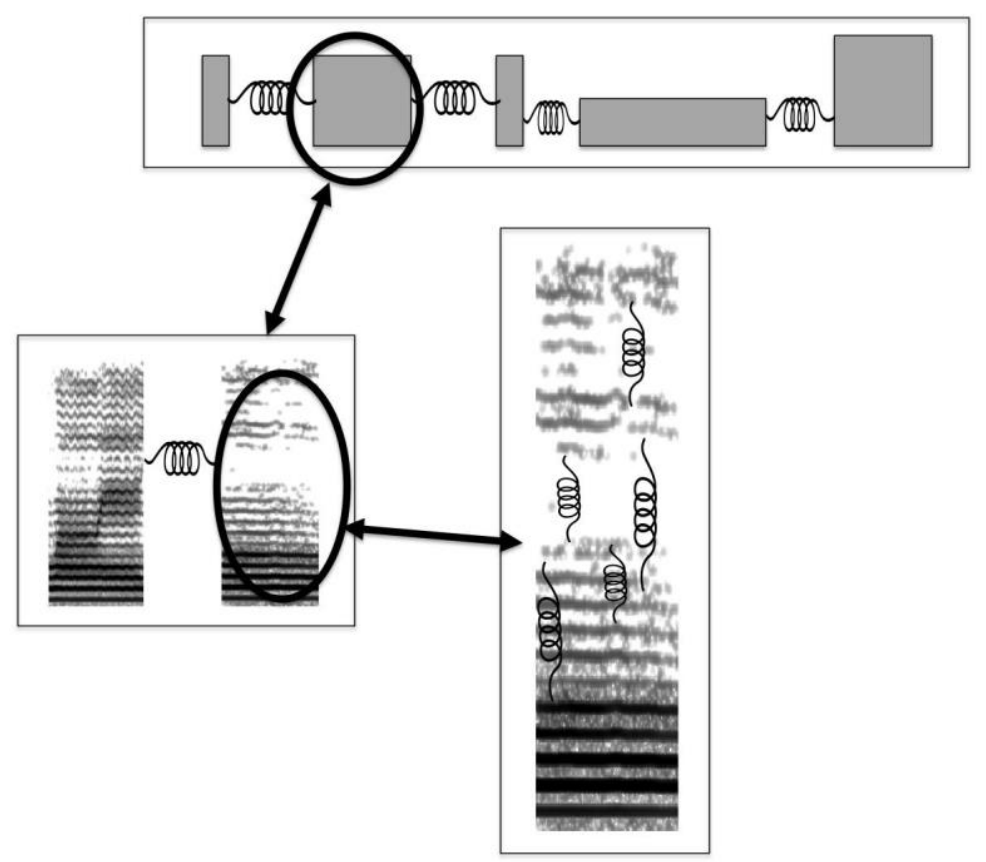

Fig. 6: imagem do modelo massa-mola projetado em nível formal (sequência), nível de objetos e nível interno (espectral)

O modelo que empregamos aqui é retirado do modelo massa-mola, em que entre cada massa há uma mola que transmite a energia de um ponto a outro. Sendo esta mola expressa por um operador, o que Gilbert Simondon em Du mode d'existence des objets techniques denomina por "alagmática". ${ }^{44}$ É neste sentido que cada momento de um fluxo musical pode estar conectado a outro por um ponto de transferência de energia, um ponto de transdução, em que um tipo de energia pode ganhar continuidade transformado em outro tipo. Um fluxo textural pode se desdobrar em uma figura, vice-versa, ou um gesto pode dar lugar a uma sonoridade.

\footnotetext{
14 Este modelo também tem por base a síntese por modelagem física, trazendo para o domínio do fluxo de performance o modelo presente em aplicativos de síntese, como Modalys (Ircam) e patches específicos em Max/Msp e PWGL, Este modelo nos permite distinguir a cadeia transdutiva de energia mecânica e acústica, e suas posteriores extensão no live-electronics, na transdução em energia eletromagnética e posterior tradução por codificação analógico-digital-analógico, destacando assim as fases de produção do som em um instrumento acústica na presença do live-electronics: 1) excitação; 2) corpo excitado; 3) corpo de ressonância; 4) mecanismo de captação (segundo corpo excitado); 5) tradução AD-DA.
} 
Muito importante aqui é uma imagem trazida por Bergson em seu curso Histoire de l'idée de temps, de 1902-1903. Ali Bergson distingue dois modos de conhecimento, relativo e absoluto. O relativo, o ver de fora, em contraponto ao absoluto, ver confundindo-se com o objeto visto. Seria esta talvez a tarefa do intérprete: fazer com que a performance permita ao ouvinte ouvir de dentro, ouvir se confundindo com o fluxo de energia aquilo que na partitura está expresso em elementos justapostos, por composição (BERGSON, 2017, p. 24-27).

Foi com base neste modelo que a partir de uma primeira versão de leitura e preparação da peça consideramos os seguintes elementos relativos ao jogo entre partitura e intenção de fluxo imaginada pelo compositor:

\section{Silvio Ferraz}

Wed, Apr 17, 8:41 PM

to William

Ufa que explosão!

Vamos lá então primeiro trabalhar todas dinâmicas chatas que escrevi.

Todo este nervoso que vc colocou nesta bela realização, mas agora imagina tudo isto contido no ppp, no pp um pouco mais sonoro (um pouco menos ruidoso).

No arco arestato, menos pressão de arco ... o arco mais parado quase uma coisa percussiva e relaxando da tormenta.

Alías... tem esta coisa que estou aqui pensando: tormenta-relaxamento de tormenta... próximolonge.

O começo: veloce, sempre flautando sul pont; il piu legato possibile; com sordino di piombo

De repente um violento ff, corta tudo mas volta ao que estava antes...cresce ao $\mathrm{mp}$ e fica oscilando pra chegar no $f$ e nos acentos stacatto desta passagem

depois volta a violência, sobre uma só nota... feio (cativo) : questo passaggio deve essere giocato violento, molto al talone, cativi e subito, sempre con una intensione molto forte, ma muto (com sordino di piombo) al mp, l'arco sempre deve essere alla corda, quasi interrotto sullo stesso punto del tallone.

a intensão é forte mas o som vem mudo, quase só se ouvem os acentos, os glissandi, a pequena apojatura em subito (que é um pouco mais $f$ que o restante em $\mathrm{mp}$ e mudo.

O arco arestato da 3 e 4a linhas... ali é o relaxamento o som que vai desaparecendo mesmo e pouco a pouco mais sonoro (altura mais definida, menos ruído) mas ainda em $m p$...

Três cortes súbitos em ff que decrescem ao nada... e o arco arestato mas com menos pressão pq é ppp.

Na linha 2 da p.3 o dó, corda solta, é quase que só resvalado (são notinhas pequenas) e sul pont... ao final da linha tudo em $\mathrm{mf}$ e mais som das notas, das frases

A violência mesmo está nas primeiras figuras da linha 4.

novo violento cativo (feio), mas lontano, pp...

E finalmente Debussy... só as notas maiores recebem um pequeno acento.

O final... perfeito, só diria para deixar ressoar o último ataque.

Cuidado, esta peça passa mto pelas cordas soltas dó e sol...não toque elas com mais força que necessário senão elas saltarão mto (erro do compositor).

Mas caramba... que peça difícil e como é incrível o modo que vc a colocou de pé. Eu fiquei até na dúvida se não era pra ser esta violência mesmo.

Mas pensei bem, e talvez a violência seja contida.

A mãe da Annita, a Nitona, fumava, tossia muito, falava alto e de repente dormia...ocupava um espaço de mil atores. Qdo ia ao teatro bastava um momento para que depois da peça o ator, no boteco falasse que ele tinha ficado tranquilo mesmo foi na hora que ouviu que a Nitona estava no público. Nos últimos dias ela já só ficava deitada e por vezes 
vinha uma risada gutural forte, mas no resto do tempo eu imaginava ela falando e rindo alto mas lá dentro do corpo.

Seria esta a imagem para ajudar a construir este personagem-peça.

Abs

Silvio

Exemplificando os dados expressos nesta mensagem trazemos abaixo as passagens nos rascunhos e na partitura final. Na primeira passagem a inserção da parte central da peça, que já estava escrita para outra peça e que, por ser justamente uma inserção, implica em um momento de mudança de sentido na peça, daí o prolongamento da nota final da figura-gesto da linha anterior (passagem da segunda para terceira linha, na partitura finalizada abaixo, fig. 8). Esta mudança de direção implica em uma mudança brusca na interpretação da peça, modo de ataque, arcada, sonoridade, e por consequência na escuta da peça. Já na segunda passagem (fig. 9) exemplificamos a passagem contínua comentada mais acima neste texto, em que a passagem de "arco arrestato" (o arco quase parado sobre as cordas, em movimento pendular sobre as quatro cordas) é uma espécie de ressonância longínqua da passagem anterior de notas reiteradas fortes.

Assim temos a passagem brusca, por corte, em que tudo muda de direção (quebra e nova trajetória do fluxo de energia) e passagem com explicação direta por ressonância longínqua. Tal exemplo nos remete à observação realizada por Paul Klee (fig.7):

[...] a justaposição de fortes contrastes engendra uma expressão cheia de força. A inserção de um meio de conexão entre os contrastes, os afasta mutuamente e enfraquece a expressão [...] Curva do movimento levando em consideração as noções de "forte contraste sem conexão" (1), "conexão" (2) e "contraste secundário" (3 e 3a). (KLEE, 1980, p. 319).

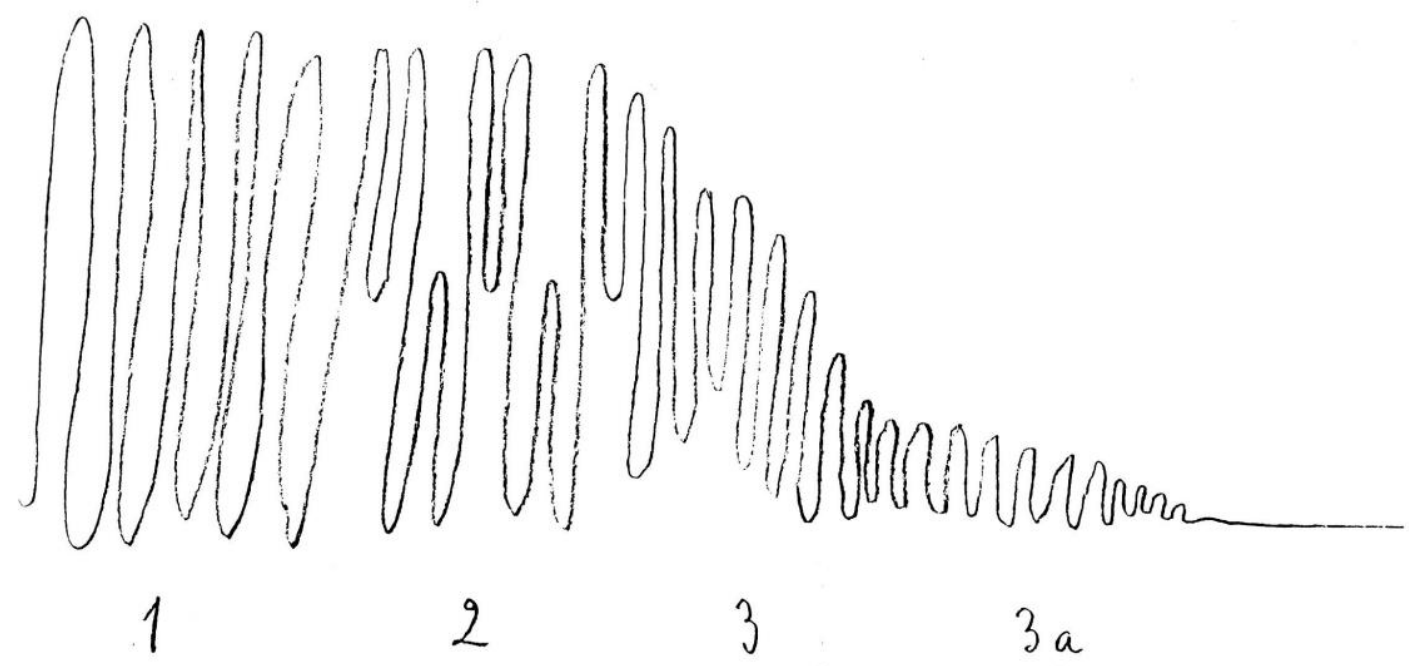

Fig. 7: desenho de Paul Klee sobre a conexões próximas ou saltos em uma linha: "'forte contraste sem conexão' (1), 'conexão' (2) e 'contraste secundário' (3 e 3a)" 


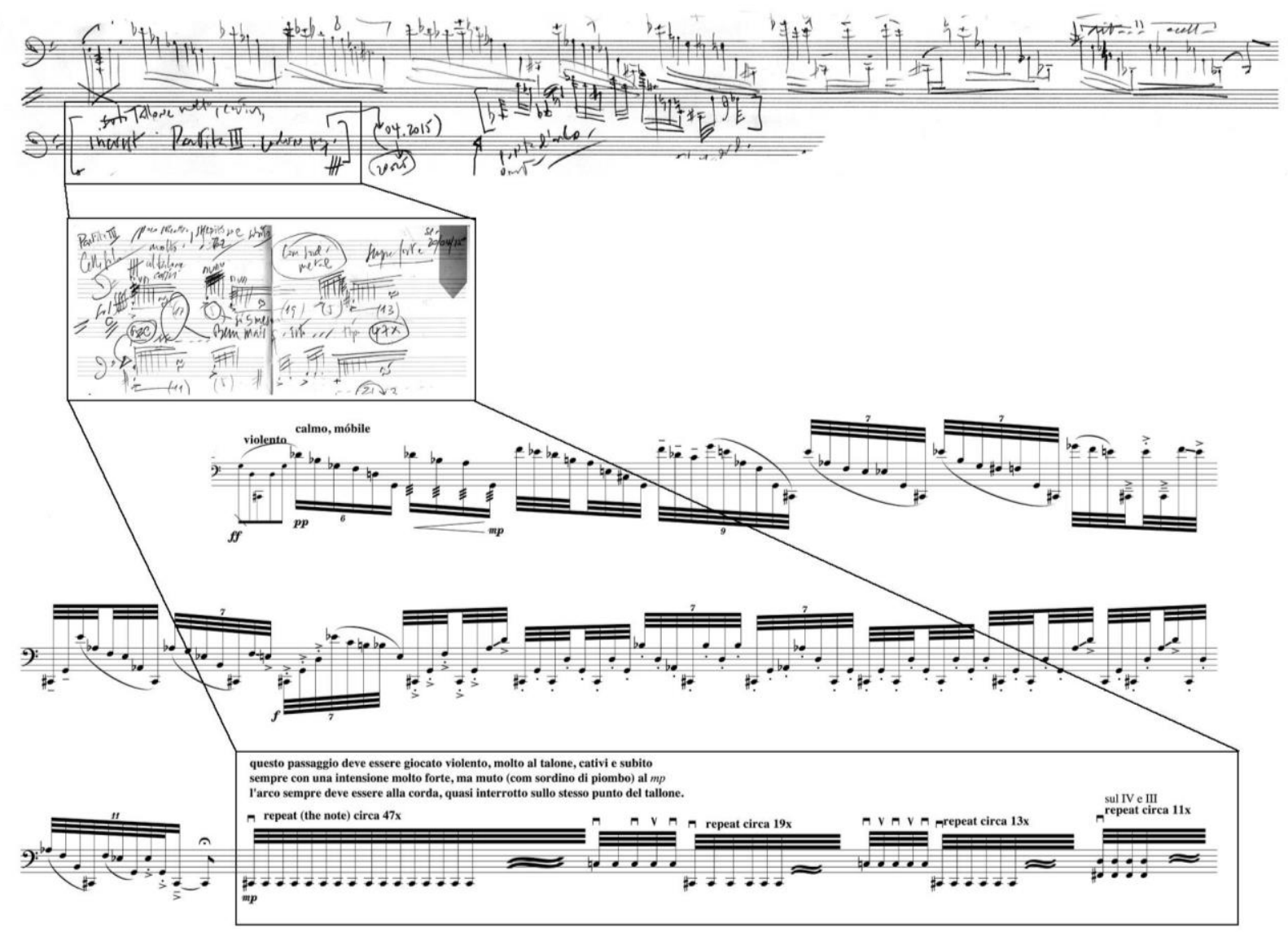

Fig. 8: passagem de Silvio, exemplificando o processo de incrustação, que favorece o salto entre objetos distantes, na etapa de rascunho (com materiais provenientes de projetos composicionais distintos) e sua presença na versão final da partitura 

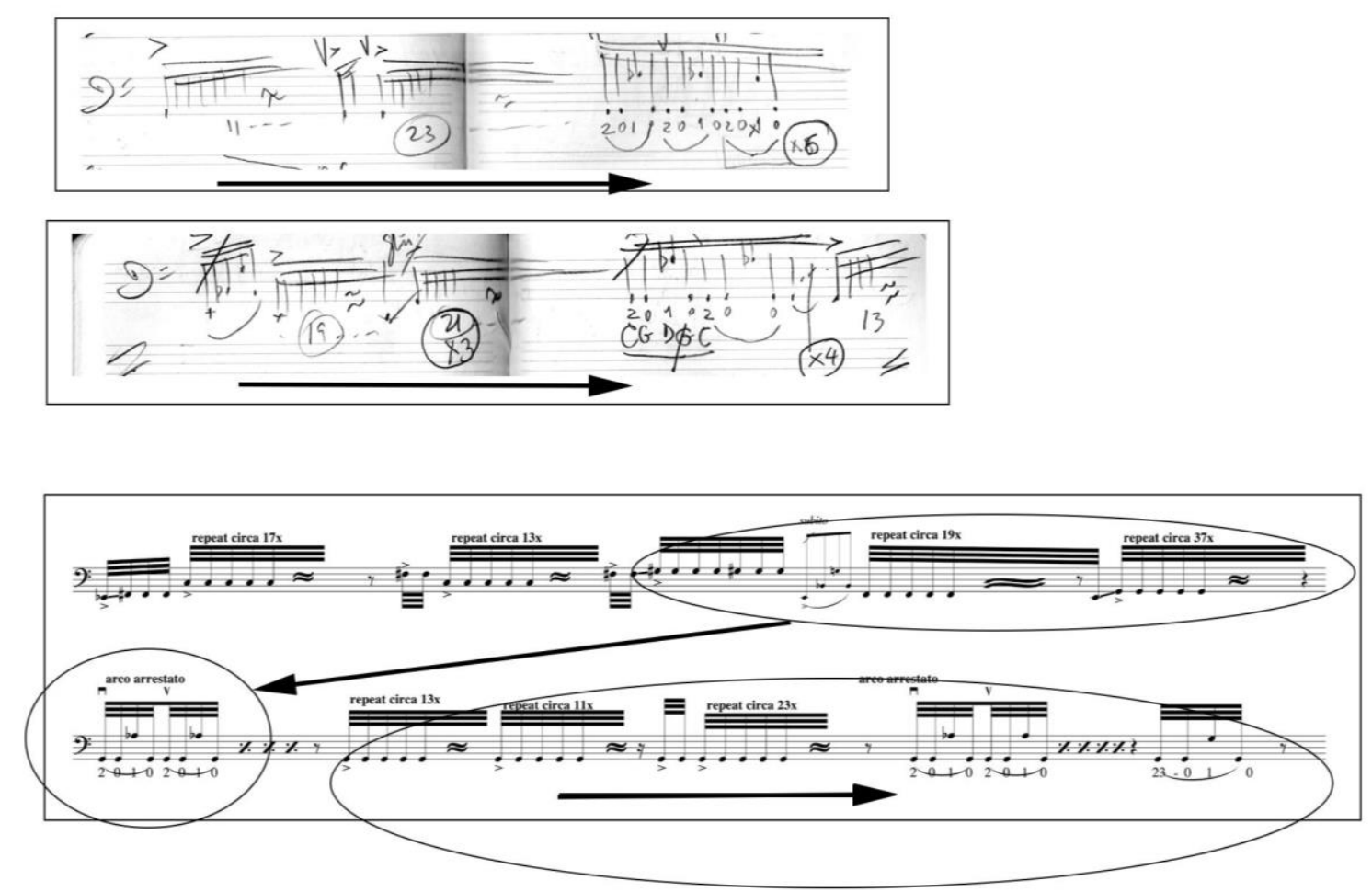

Fig. 9: rascunho e versão final de transformação linear de um fluxo de energia, da forte reiteração de notas à sua ressonância com "arco arestato" em bariolage

\section{Segundo parênteses: a presença do compositor na expressão do pensamento interpretativo (William)}

A questão do conhecimento absoluto bergsoniano antecipa uma questão fundamental: que é uma performance? Essa questão, obviamente, só faz sentido quando não apenas as entidades da composição e da performance estão dissociadas, mas quando o acesso ao conhecimento da primeira por parte da segunda está corrompido ou impossibilitado por algum tipo de distância. Como lembra Lawrence Dreyfus, a origem do termo performance na língua inglesa se dá em um primeiro momento exclusivamente em contextos onde se refere ao cumprimento de uma promessa feita, ou seja, àquele responsável pela performance de uma promessa proferida (Dreyfus, 2007). Dessa ideia prossegue, portanto, o segundo componente do problema, que é o cumprimento fiel da promessa realizada.

A noção de uma procissão promessa-cumprimento fiel não se apresenta como um problema tão grave quando seu responsável é uma única entidade pessoal; o problema existe efetivamente apenas quando se assume uma lacuna de informação entre duas entidades distintas, ou seja, quando aquele responsável pelo cumprimento não possui informações suficientes para intuir sobre o conteúdo da promessa que deve cumprir. É nesse ponto que o divórcio entre as entidades da composição e da performance acontece e onde a ideia da 
prevalência de uma sobre a outra se torna a única via possível para se solucionar a questão. É justamente essa a via que tem sido por regra a premissa básica para estudos em performance musical, que concluem em uma inevitável bifurcação: ou se escolhe a submissão à vontade do compositor ou a performance assume o papel de criadora de significado do discurso musical, libertando-se da opressão daquela entidade autoral, tida como autoritária ${ }^{15}$. Embora essa discussão pudesse se desdobrar em uma teoria da autoridade musical, nesse momento há um componente tácito que oferece uma saída anterior e mais efetiva para nosso dilema: a pressuposição que a lacuna entre compositor e performer é de informação.

Partindo da compreensão já defendida da composição como o imprimir de um fluxo de energia e a performance como o materializar desse fluxo, nega-se, portanto, que é de ordem informacional que a conexão entre composição e performance consiste, mas sim energética. É claro que não se ignora a distância estrutural que pode haver entre campos notacionais, isto é, textuais, distintos, seja por tempo ou espaço. Essa exegese é parte fundamental de uma abordagem imanente do discurso musical, no entanto, a etapa da decifração é apenas a base para o desenvolvimento de uma interpretação como a que está em questão. Colocando mais claramente: a questão não é em que ponto a Partita deixa de ser de Silvio para ser de William, mas como ela poderia consistir em um fluxo de energia em que a entidade composicional Silvio se atualiza na entidade interpretativa William ponto a ponto (de proche en proche). Retomamos novamente um processo como a alagmática proposta, onde a premissa da substância, seja ela em transubstanciação ou consubstanciação, não precisa da diluição da entidade composicional enquanto mero dado memorial para se resolver, mas encontra uma terceira via onde a presença do compositor é real na performance na medida em que energiza o discurso musical em seu fluxo.

Talvez essa compreensão seja dificultada por sermos oriundos, no Ocidente, de uma tradição artística que ainda tem o compositor como um gênio cuja criação "divinamente inspirada" deva ser obedecida literalmente (literalisticamente seria mais preciso), sob o risco de se violar sua Vontade. A presença real que proponho aqui, entretanto, não é dessa ordem. Não deveria se levar em conta o terrível antissemitismo de Wagner para compreender seus encadeamentos harmônicos, por exemplo, nem mesmo poderia se intuir qualquer misoginia ou incitação ao estupro por parte de Beethoven por conta das cadências interrompidas de sua Nona Sinfonia ${ }^{16}$. Tais considerações só ocorreriam em abordagens de cunho sócio-histórico

\footnotetext{
${ }^{15}$ Essa noção é premissa básica em todo o campo musicológico denominado como Musical Performance Studies e pode ser observada especialmente nos capítulos de Colin Lawson, Peter Walls e John Rink em John Rink (org), Musical Performance: a guide to understanding, Cambridge: Cambridge University Press, 2002.

${ }^{16}$ Refiro-me à tese de Susan McClary em Feminine endings: music, gender, \& sexuality, 2. ed., Minneapolis: University of Minnesota Press, 2002.
} 
que ainda se atém a aspectos estruturais, esquecendo-se do universal que os antecede: a humanidade do sujeito e, portanto, da música ${ }^{17}$.

Como maneira de evitar tais mal-entendidos, o filósofo Alexander Nehamas (1986, p. 686) propõe duas categorias simples para a compreensão da ação autoral, a partir das quais é possível entender mais claramente de qual presença defendo a realidade, distinguindo o escritor, isto é, o indivíduo localizado na história que causa eficientemente seu texto, do autor, a pessoa implicada no texto e acessível em sua imanência. "O escritor dá conta da existência do texto, mas o autor (implícito) dá conta de seu significado". O autor, dessa forma, "é a figura implicada por diversos textos tomados em conjunto", sendo uma "variante histórica plausível do escritor" (VANHOOZER, 2005, p. 286-288), sendo não apenas um outro nível de heteronomia causal, mas uma implicação das ações criativas do escritor. É esse o nível de autoria, portanto, que pode ser inferido da composição no fluxo de energia contido em um discurso musical. Ainda que a pessoa do compositor (escritor) afete inevitavelmente seu ato composicional (autor), interessa aqui acessá-lo não na medida em que se adentra sua vida privada, mas no âmbito de seu trabalho imediato de imprimir um fluxo de energia, seja por uma análise imanente que envolva manuscritos ou diálogos, seja por meio do próprio texto da partitura, que estabelece as conexões fundamentais das quais consiste a peça.

Essa atitude está presente em todas as ações interpretativas anteriormente descritas, ou seja, em todas as etapas do preparo da peça. Mas é importante notar onde ela mais intensamente acontece, de maneira a suplantar todas as demais: na performance. O crítico George Steiner define perfeitamente o que quero dizer:

A verdadeira hermenêutica do drama é encenar (até mesmo a leitura em voz alta de uma peça, geralmente, vai muito além de qualquer resenha teatral). Por sua vez, nenhuma musicologia, nenhuma crítica musical pode nos dizer tanto quanto a ação de significado [ou de significar] que é a performance. (STEINER, 2013, p. 13).

Isso porque a natureza do significado musical não é denotativa, mas existencial, para fazer uso das categorias do filósofo Michael Polanyi (1962, p. 60). É só em viver plenamente (corpo, intelecto, espírito) um fluxo de energia que se pode acessar o fluxo de energia que pressionou o compositor a expressá-lo, imprimindo-o em sua escrita. Nesse acontecimento reside a conexão que torna a composição uma força presente na performance e não apenas como uma entidade apriorística.

A performance é o cumprimento de uma promessa feita pelo compositor em seu artesanato, mas não depende de uma gnose, de um conhecimento revelado, para que seja possível. A natureza dessa promessa é que precisa ser esclarecida. Trata-se não de um contrato social, onde os termos possuem valor vinculante, mas sim de uma ação realizada na

\footnotetext{
17 Para uma proposição mais ampla, ver Teixeira e Ferraz, 2017.
} 
estrutura. É disso que consiste a Teoria dos Atos de Fala de J. L. Austin, quando o filósofo inglês distingue a força ilocucionária (o que é feito) da força locucionária (o que é dito) ${ }^{18}$. 0 famigerado exemplo de Austin nos serve bem, pois ele diferencia a promessa que é feita no altar matrimonial, da palavra dita na ocasião (por exemplo, o "sim"): a promessa é feita em se dizer o sim. A performance possui essa força ilocucionária, portanto, de maneira que não é de estrutura (de informação) que depende seu vínculo com a composição, mas da energia implicada em seu fluxo, ou seja, daquilo que ela $f a z^{19}$.

Prossegue dessa compreensão uma imagem que tem me acompanhado nesse processo de construção da interpretação da Partita: o rio. Não tanto o rio de Heráclito, que se define, ainda que em sua fluidez, pelo homem que nele se banha, mas o rio enquanto materialização de um fluxo de energia, irreversível e impossível de nele se estar. Nesse rio apenas se mergulha, se imerge integralmente na velocidade do movimento de suas correntes. Essa imagem proporciona uma analogia precisa para retratar como o fluxo de energia poderia se desenvolver em uma teoria musical correspondente às suas premissas. $O$ funcionamento de um rio pode ser observado por duas perspectivas: sua geomorfologia e sua hidrologia. Ambas são fundamentais para que o fluxo de energia resultante seja compreendido adequadamente. Do ponto de vista da geomorfologia, um rio é composto por suas dimensões longitudinais (seu continuum, a direção de seu fluxo), laterais ("ligação entre os elementos e processos de um sistema, os quais definem o estágio de suas variáveis"; CORRADINI; FACHINI; STEVAUX, 2006, p. 13), verticais (dinâmicas de profundidade) e temporais (sua dinâmica no-tempo, kairótica, sazonal; STEVAUX; LATRUBESSE, 2007, p. vi). É importante reconhecer que os quatro aspectos se dão no fluxo do tempo, razão pela qual oferecem uma visão menos arquitetural e mais morfológica da formação estrutural. E é essa formação que interessa à performance: a compreensão do processo formativo empregado pelo compositor para que seja possível adentrar os fluxos ali implicados, compreendendo-se quais são as conexões, como os objetos se formam ou se separam e como se relacionam com suas vizinhanças no jogo transdutivo de passagem de energia de um ponto a outro. Essa morfologia, no entanto, não determina fatal e causalmente quais serão as correntes que por ali passarão. Um complexo de condições torna essa dinâmica extremamente variável, de maneira contingente à formação de seu leito, sua temperatura, altitude, volume, dentre tantos outros componentes.

\footnotetext{
${ }^{18}$ Restaria o terceiro nível de agência, que é a força perlocucionária, isto é, aquilo que é feito no outro (AUSTIN, 1962, p. 2).

${ }^{19}$ É esse conceito de Austin que leva Deleuze e Guattari a concluírem uma superação do paradigma estrutural. A terceira consequência da Teoria dos Atos de Fala para a linguagem é "A impossibilidade de manter a distinção línguafala, visto que a fala não pode mais ser definida pela simples utilização individual e extrínseca de uma significação primeira, ou pela aplicação variável de uma sintaxe prévia: ao contrário, são o sentido e a sintaxe da língua que não se deixam definir independentemente dos atos de fala que ela pressupõe" (DELEUZE; GUATTARI, 1995, p. 15, v. 2).
} 


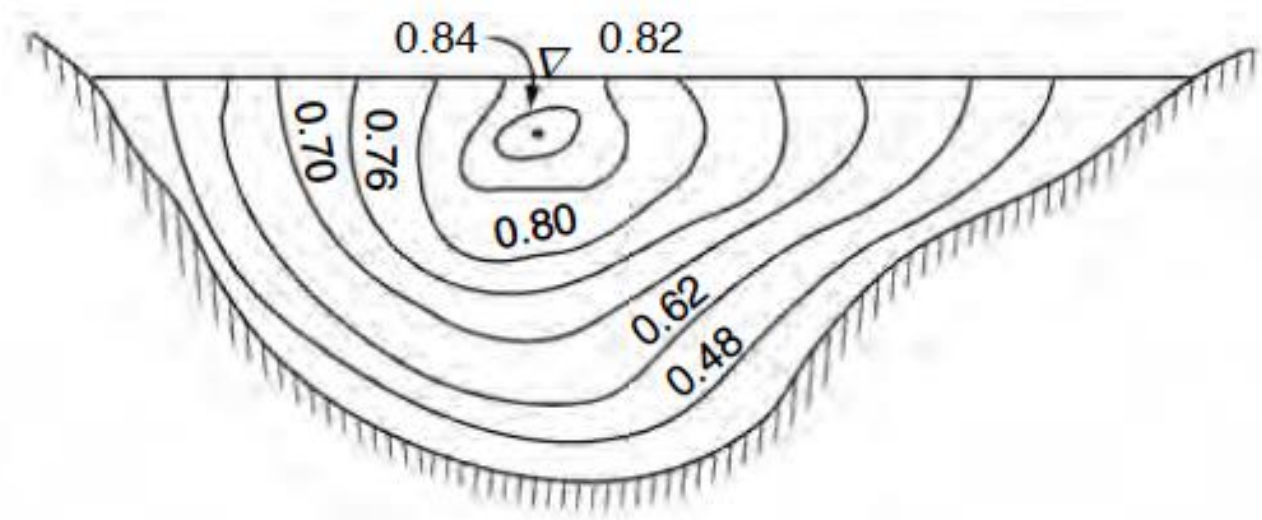

Fig. 7: variabilidade média de velocidade das correntes em rio de curso natural (SUBRAMANYA, 2009, p. 6)

É dessa forma que vejo a hermenêutica demandada pelo fluxo de energia da música: um navegar com frágil remo, onde se escolhe uma dentre inúmeras correntes dentro do rio. O significado, nessa analogia, refere-se mais à direção do rio, à sua dimensão longitudinal. No entanto, o rio possui diversas correntes, até as mais marginais, proporcionando, dessa forma, quantidades de performances múltiplas. Um mesmo performer, aliás, pode adotar ora uma corrente, ora outra, e ainda assim permanecer dentro da direção do fluxo de energia. Em uma peça como a Partita, o desafio é justamente adentrar a intensa corredeira que em sua primeira nota já desencadeia uma energia instantaneamente alta e duradoura. O que precede essa descarga que rompe o silêncio? Energia.

Uma questão, no entanto, é importante de ser pontuada: o rio possui bordas. O rio possui limites entre o que pertence à sua dinâmica, ao seu fluxo, e o que não pertence. Dessa forma, a quantidade de performances é múltipla, mas não infinita. Porque não há apenas uma interpretação, não se está no campo onde qualquer coisa ganhe validade, mas onde algumas coisas correspondam à energia proposta pela composição. Assim, a performance elege correntes que pertencem ao fluxo, tendo condições até mesmo de saltar de uma corrente para outra em uma mesma performance, permanecendo no fluxo. As condições morfológicas construídas pelo compositor formam um campo de dinâmicas particulares - uma peça -, cabendo ao performer encontrar seu caminho junto ao fluxo do rio, navegando ativamente nele.

Essa analogia parece resolver a aparente concorrência de que haja entre compositor e performer uma relação baseada na velha metáfora de um déspota tirano e um súdito submisso, para ser redundante. Não há escolha a ser feita entre qual dos dois opera as rédeas da música. Ambos participam em suas forças próprias para a produção do fluxo de energia de uma mesma música. Não há porque se levar em conta, como propõe John Rink, que "ao avaliar a função e a importância relativa desses elementos [musicais], as intenções do compositor (variáveis?) não têm autoridade primordial, embora possam não ser totalmente 
irrelevantes", porque, se por um lado, seria ilógico não se reconhecer uma ação autoral no ato da composição, por outro, não há uma autoridade do compositor que possa anular a performance. A composição é extrema e genuinamente relevante, pois é ela que forma o leito, as bordas e o fluxo de energia do rio. Não há concorrência alguma, no sentido de que exista alguma competição entre o compositor e o performer. Há sim uma outra acepção de concorrência entre ambos, mas no sentido de que correm juntos. A presença do compositor acompanha o performer na medida em que este adentra a corrente de um fluxo de energia e é por ela direcionado, ao mesmo tempo que conduz ativamente seu próprio caminho nela. A superação da distância informacional entre composição e performance redefine assim a problemática colocada anteriormente; não se trata de se perguntar "o que é a performance?", pois cumprimento e promessa se atualizam ponto a ponto, não bastando nessa aliança concorrente e complementar uma ação derradeira para que a promessa se cumpra, já que é o estar no fluxo que garante isso. Sendo assim, a questão mais precisa seria: o que pode uma performance?

\section{Notas finais: diálogo apócrifo ou uma contra-conclusão (Silvio e William)}

S - Uma coisa importante é dizer que: Ao se pensar a performance assim, como analista de seu próprio trabalho, cai-se em uma pequena armadilha. Que mesmo não sendo negativa, é uma armadilha. As palavras que usamos, os métodos analíticos, nossa visão, toda ela está moldada, e com isto corremos o risco de engessar a própria performance. Seria uma espécie de imposição do descontínuo da linguagem e dos métodos sobre o contínuo do gesto e da performance. Falando sobre si, podemos inventar um "em si".

W - Interessante mencionar isso, sem dúvida. Até porque esse é um aspecto que costuma me afastar de ler textos escritos por performers ou nessa área de "criação colaborativa": o grau extremo de subjetivismo, que não desabona, porém incorre ao risco de parecer uma mera opinião e, portanto, parecer dispensável. Soluções tão particularizadas que têm dificuldade em vislumbrar aplicações mais gerais, isto é, para outros. No nosso caso, uma coisa que creio que nos resguarda é uma clareza nas responsabilidades implicadas: vc é o compositor e eu sou o violoncelista. Ainda que nos afetemos mutuamente, existe um componente ético que define a responsabilidade última por cada tomada de decisão.

Dito isso, a simultaneidade de nossa discussão talvez não seja de um contágio tão imediato quanto parece. Quisera eu que fosse! A transdução, digamos assim, do conceito para o bloco de sensações demanda muito esforço e planejamento: técnica. Sendo assim, os conceitos que discutimos apontam caminhos, mas que para serem trilhados ainda assim demandam muito esforço. Então não sei se esse engessamento pode acontecer tão imediatamente, pelo menos não como uma relação de causalidade direta de nossa reflexão. 
Existe um componente que me dá certa proteção contra os ataques do descontínuo da linguagem: o palco. No fim do dia, tenho que fazer funcionar quando subir lá...

S e W - Este artigo é um relato, uma reflexão conceitual, mas acima de tudo uma fabulação musical de prática-como-pesquisa (PACE, 2016). Uma fabulação que partiu de uma espontânea geração, tendo o diálogo aqui presente em forma de palavras, sons e gestos como um recorte de tantas forças-referências concomitantes ao processo de construção da performance. Nesse sentido, este artigo se inscreveu em nosso processo quase que como uma meta-colaboração, uma reflexão colaborativa sobre a colaboração e que, por essa razão, nos fez pensar não só o que é fazer música colaborativamente, mas também como seria reproduzir de maneira adequada os meios através dos quais esse processo se estruturou. Por isso, temos abandonado a ideia cara às ciências humanas de tomar o artigo como obra, para adotarmos uma ética mais próxima daquela das ciências naturais onde o artigo é o relato de uma pesquisa, narrando seus processos sem se confundir com ela, tomando para si um caráter provisório, o que parece próprio de uma postura acadêmica diante do conhecimento. Alguns princípios foram apresentados objetivando serem impulsos para a criação musical, tanto composicional quanto interpretativa. Por essa razão, as autorias das palavras por vezes são distinguidas: mais enquanto agenciamentos, do que como demarcações de poder (DELEUZE; GUATTARI, 1995a, p. 11); como potências responsáveis e não como hierarquias; nem como uma voz épica objetivamente onisciente, ou uma voz lírica subjetivamente revelada, mas como drama, isto é, como um roteiro de ações que desencadeiam umas às outras (VANHOOZER, 2016).

Enfim, a colaboração aqui apresentada, longe de ser um fim em si mesma, se apresenta neste final como um aspecto de permanência do processo, que inevitavelmente contou com muito mais constantes solidões. Mas a capacidade de conectar conceitos e sensações que a música possui também permite que essas agências se conectem e se fundam no devir que uma peça-objeto possui de superar seu claustro estrutural, ganhando vida no mundo.

Esse mundo que um processo como o aqui descrito revela possui tal estatuto por pelo menos duas razões: em primeiro lugar porque a própria arte possui o atributo de projeção de um mundo (WOLTERSTORFF, 1980), ou, como temos entendido em outro lugar, como o projetar de uma realidade afetiva (TEIXEIRA; FERRAZ, 2018). Em segundo lugar, porque sendo música aquilo que pessoas fazem em realizarem ações musicais (TEIXEIRA; FERRAZ, 2017), ela assume como seu princípio básico este agenciamento, isto é, de pessoas. Pessoas fazem música e pessoas fazem o mundo, razão pela qual qualquer realização artística e, em nosso caso, a realização musical especificamente, congrega um mundo multimodal em torno de si. Dessa maneira, consideramos este escrito como uma tentativa de fazer jus às forças implicadas em uma realização musical que poderia ser fonograficamente objetificada em poucos três minutos, colocando no tempo que há nela e a partir dela (BECKER, 1982, p. 5). 


\section{Referências}

AUSTIN, J. L. How to do things with words. Londres: Oxford University Press, 1962.

BARRIÈRE, J.B. Le timbre, métaphore pour la composition. Paris: IRCAM, 1991.

BECKER, Howard S. Art worlds. Berkeley: University of California Press, 1982.

BERGSON, Henri. Histoire de l'idée de temps: cours au Collège de france, 1902-1903. Paris: PUF, 2017.

BREGMAN, Albert. Auditory scene analysis. Cambridge, MA: MIT Press. 1994.

BOULEZ, Pierre. Penser la musique aujourd'hui. Paris: Denoë//Gonthier, 1963.

CORRADINI, F. A.; FACHINI, M. P, STEVAUX, J. C. Controle geomorfológico da distribuição da vegetação ripária do rio Paraná. Parte I - Unidades geomórficas da planície de inundação. Revista UnG-Geociências, v. 5, n. 1, p. 13-21, 2006.

DELEUZE, Gilles; GUATTARI, Félix. Mil platôs: capitalismo e esquizofrenia. Tradução: Ana Lúcia de Oliveira e Lúcia Cláudia Leão.São Paulo: Editora 34, 1995a. v. 1.

DELEUZE, Gilles; GUATTARI, Félix. Mil platôs: capitalismo e esquizofrenia. Tradução: Ana Lúcia de Oliveira e Lúcia Cláudia Leão.São Paulo: Editora 34, 1995b. v. 2.

DOSSE, François. História do estruturalismo: o campo do signo - 1945/1966. Tradução: Álvaro de Cabral. Bauru: EDUSC, 2007.

DREYFUS, Laurence. Beyond the interpretation of music. Dutch Journal of Music Theory, v. 12, n. 3 , p. 253-271, 2007.

FERRAZ, Silvio; TEIXEIRA, William. Técnica estendida e escrita polifônica em Luciano Berio: Sequenza XIV. In: MENEZES, Flo (org.). Luciano Berio: legado e atualidade. São Paulo: Editora Unesp, 2015.

FERRAZ, S. Kairos: ponto de ruptura. Ouvirouver, Uberlândia: UFU, v.11, 2015.

GAGNEPAIN, Xavier. Du musicien en general... au violoncelliste en particulier. Paris: Cité de la musique, 2003.

KLEE, Paul. La pensée créatrice. Paris: Dessain et Tolra, 1980.

LACHENMANN, Helmut. Écrits et entretiens. Genève: Contrechamps, 2009.

MAUS, Fred Everett. Concepts of musical unity. In: COOK, N. and EVERIST, M. (eds.). Rethinking Music. Oxford: Oxford University Press, 1999.

MORGAN, Robert P. The concept of unity and musical analysis. Music Analysis, v. 22, n. 1/2, 2003

NEHAMAS, Alexander. What an author is. Journal of Philosophy, 83, 1986.

PACE, lan. (2016). Composition and performance can be, and often have been, research. Tempo, 70(275), p. 60-70.

POLANYI, Michael. Personal knowledge: towards a post-critical philosophy. London: Routledge, 1962.

RINK, John. "Performer's analysis" and the emergence of musical understanding. In: MÚSICA

Analítica 2019: Porto International Symposium on the Analysis and Theory of Music. Porto:

Universidade Católica do Porto, 2019.

SIMONDON, Gilbert. Sur la technique. Paris: PUF, 2014.

SIMONDON, Gilbert. Communication et Information: cours et conférences. Chatou: Editions de la transparence, 2010.

STEINER, George. Real presences: is there anything in what we say? New York: Openroad, 2013. 
TEIXEIRA, William. Por uma performance retórica da música contemporânea. Tese (Doutorado), USP, 2017.

TEIXEIRA, William; FERRAZ, Silvio. Música como ação. Revista Vórtex, v. 5, p. 1-12, 2017.

TEIXEIRA, William; FERRAZ, Silvio. Affects of chaos: Rhetorical pathos and the epistemology of musical discourse. Zbornik Akademije umetnosti, 2018(6), p. 64-88, 2018.

STEVAUX, J. C.; LATRUBESSE, E. M. Geomorfologia fluvial. São Paulo: Oficina de textos, 2017.

SUBRAMANYA, K. Flow in Open Channels. 3. ed. Nova Delhi: McGraw-Hill, 2009.

VANHOOZER, Kevin. Há um significado neste texto? Interpretação bíblica: os enfoques contemporâneos. São Paulo: Vida, 2005. Tradução de Álvaro Hattnher.

VANHOOZER, Kevin. Sapiential Apologetics: The dramatic demonstration of gospel truth. In: Pictures of an theological exhibition. Downers Grove: InterVarsity Press, 2016.

WOLTERSTORFF, Nicholas. Works and worlds of art. Oxford: Oxford University Press, 1980. 